\title{
PARAMETERS AND INDICATORS OF MILK TRUCK FUNCTIONING AT DAIRY PROCESSING ENTERPRISES
}

\author{
Anatoliy Tryhuba ${ }^{1}$, Vitalij Grabovets ${ }^{2}$, Liudmyla Mikhailova ${ }^{3}$, Anatolii Rud ${ }^{3}$ \\ ${ }^{1}$ Lviv National Agrarian University, Ukraine; ${ }^{2}$ Lutsk National Technical University, Ukraine; \\ ${ }^{3}$ State Agrarian and Engineering University in Podilya, Ukraine \\ trianamik@gmail.com,vgrabovets@ukr.net,dakgps@pdatu.edu.ua
}

\begin{abstract}
The analysis of existing methods of determining automobile fleet parameters at the area is carried out and their disadvantages are substantiated. The proposed method of substantiation of the parameters of the milk trucks of the dairy enterprise involves the implementation of five complementary stages. The first stage provides the creation of a database of production conditions and characteristics of vehicles. The second stage involves the definition of rational customary routes for the delivery of milk from the points of harvesting to the milk processing enterprise for variants of the fleet of cars with the same cargo. In the third stage, the calculation of the functioning indicators is carried out, the needs for identical cargo vehicles and their basic parameters are determined. The fourth stage provides the definition of rational local routes for variants of the fleet of cars with different cargo. The fifth stage involves the indicator calculation of the milk trucks functioning and the definition of effective parameters for dairy processing enterprises, which provide the minimum cost of resources for their operation. It is established that with the increase of cargo tank truck capacity from 1.3 to 11.5 tons, their average daily run in the intensive milk harvesting period is reduced from 2.64 to 0.57 thousand $\mathrm{km}$, which is described by a second degree polynomial. At the same time, the need for tank trucks for these conditions is reduced from 12 to 5 units. An efficient variant of the transport infrastructure of the dairy processing plant involves the attraction of 6 cars with a cargo capacity of 3.7 tons and trailers with a cargo capacity of 0.9 tons. The proposed method and the results of the conducted researches underlie the creation of an information support system for decision making in logistics systems of milk procurement. They also underlie the planning of the transportation infrastructure of the dairy enterprise.
\end{abstract}

Keywords: milk, provision, processing enterprise, indicators, functioning, milk truck.

\section{Introduction}

There is a problem of food security in the world. It is somewhat specific for Ukraine. With the accession of Ukraine to the world trade organization, it became even more acute. This is largely due to the production of dairy products and the harvesting of raw milk. The producers of milk in Ukraine are households that provide $80 \%$ of their income to processing enterprises. At the same time, the quality of the dairy production depends to a large extent on the efficiency of the milk harvesting system. At the same time, the tasks of determining the effective parameters of tracks at dairy processing enterprises, which depend to a great extent on the conditions of production, remain out of the question.

Specific methods and models should be used to form tracks for dairy processing enterprises. The indicated methods and models should take into account features of the production conditions of milk production (the presence of milk producers, their territorial location, seasonality and milk production, the state of the network of roads, etc.). This greatly affects the parameters of milk trucks at dairy enterprises and functional indicators of the tanker use.

To substantiate the parameters of the road tanks of dairy enterprises, there should be appropriate theoretical foundations and methods and models that form the toolkit for making quality management decisions. To identify the state of science in this direction, an analysis of a number of scientific works has been carried out. In particular, scientific work [1] relates to the planning of the fleet during the servicing of seaports. In scientific papers [2-5], it is proposed to improve the efficiency of the fleet of cars using various criteria for its evaluation (cost, impact on the environment, etc.). In scientific papers [6-8], issues related to efficiency increase of the freight vehicle use are considered. However, it is not possible to use these scientific works to justify the parameters of the milk trucks of dairy processing enterprises, since they do not apply to perishable goods to which milk belongs, where the quality and duration of cargo delivery should be used according to the criteria.

A number of scientific papers [9-11] indicate that the definition of functional indicators of cars requires modeling of their work. However, these scientific works cannot be used to justify the parameters of milk trucks of milk processing enterprises, because they do not take into account the seasonality of cargo volume transportation during the calendar year and the specific production 
conditions of individual enterprises. Noteworthy are the scientific works [12; 13], which outline the peculiarities of the forecasting production conditions and the study of transport processes of milk harvesting on the basis of simulation. However, in the scientific paper [14] it is proved that each dairy enterprise has specific production conditions and needs specific research to justify the parameters of their milk trucks.

Known scientific papers [15-17], which partially take into account the production conditions of milk transportation, provide volume prediction of the transport work. However, they are intended for the harvesting of milk from households [18-19], which does not adequately reflect the conditions for determining the parameters of vehicles of dairy processing enterprises. Based on the above analyzed scientific works, it can be said that they cannot be used to determine the parameters of milk trucks of milk processing enterprises, because they have a number of shortcomings. In particular, they do not take into account: 1) the seasonality of transport operations; 2) restriction on the duration of milk transportation, which determines the quality of cargo delivery; 3) use of tank-vehicle working time during a working change; 4 ) the presence of different cargo on the market of tank-vehicles etc.

Therefore, the purpose of the work is to determine the parameters of dairies, taking into account the seasonality, duration of transportation, working hours and types of milk trucks.

\section{Materials and methods}

We have developed a method of substantiating the parameters of milk trucks of dairy processing enterprises, which eliminates the above-mentioned shortcomings. This method involves the implementation of five steps (Fig. 1). This method is based on the system approach, the theory of routing and purposeful iterative studies of the operation parameters of the tank vehicle fleet, subject to changes in its parameters. This makes it possible to determine the cargo capacity of tank-vehicles, where the transport of all the volume of harvested milk requires minimal resources.

1. Formation of the database on the production conditions and characteristics of vehicles

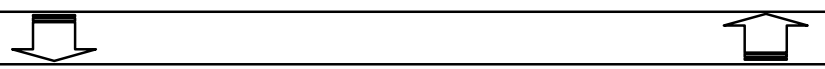

2 . Determination of rational local routes for the delivery of milk from the provision points to the dairy processing plant for the fleet of vehicles with the same capacity

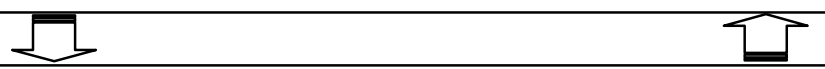

3. Calculation of indicators of the specialized road tanks functioning, determination of requirements for cars of identical load and their basic parameters

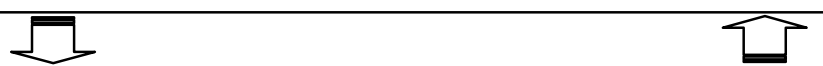

4. Definition of rational local routes for variants of a tank-car park with different load-carrying

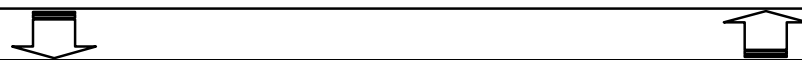

5. Calculation of specialized road tank indicator functioning and definition of car fleet effective parameters for the dairy enterprise

\section{Fig. 1. Stages of parameter substantiation for transport infrastructure at dairy enterprise}

This load capacity is the base for finding an efficient fleet of tankers with different loads. This search is carried out on the basis of iterations. Considering different variants of milk truck operation (with different load of vehicles) in all periods of the season of harvesting allows us to find rational (optimal) parameters of the tank fleet at dairy processing enterprise.

At the first stage, the presence of milk procurement points, their productivity at different periods of the harvest season is investigated. The presence on the market and specifications of tankers for milk transportation, equipment for loading and unloading of tank-vehicles, refrigeration equipment of procurement points, etc. are explored.

The second stage involves the definition of rational customary routes for the delivery of milk from the points of harvesting to the milk processing enterprise for variants of the car fleet with the same 
cargo. To do this, we use the method of determining the approximate routes, developed in the work [1].

At the third stage, the calculation of the milk truck functioning indicators is carried out, as well as the definition of needs in cars of equal cargo and their basic parameters. At this stage, first of all, there is a selection of routes for individual car enthusiasts. Indicators of the functioning of the milk trucks are the way of tank vehicles, the cargo turnover, the length of service of individual routes and the need for tank-vehicles. They are determined on the basis of simulation of the use of tank vehicles on individual routes.

The fourth stage of the proposed method involves the definition of rational public routes for different variants of car fleet with different loads. For this purpose, in relation to the determined basic load of tank vehicles, possible variants of their fleet with different loading capacity are substantiated.

The fifth stage involves the calculation of milk truck functioning indicators and the definition of effective parameters of the car fleet for the dairy enterprise. Using the cost criterion for assessing the cost of resources for the functioning of the milk trucks and the amount of investment for its formation, the effective parameters of the tanker fleet at the dairy enterprise are determined.

The developed method of substantiating the parameters of the milk trucks at the dairy enterprise has practical application. Investigation of milk truck functioning indicators at the dairy enterprise was carried out for the conditions of PJSC "Brody Plant of Dry Skim Milk" in Brody, Lviv region. Based on the developed computer program, the functioning of the milk trucks at the milk processing enterprise was modeled, which enabled to determine the functional parameters of the tank vehicle use for eleven variants of their capacity.

According to the results of the conducted researches, trends of changing the functional parameters of the tank vehicle use for changes in their load capacity have been determined (Fig. 2-5).

The obtained dependence of the total daily traversed path $(L)$ of tank vehicles on their payload $(Q)$ is described by the polynomial of the fourth degree:

$$
L=9 \cdot 10^{-4} \cdot Q^{4}-3.08 \cdot 10^{-2} \cdot Q^{3}+0.36 \cdot Q^{2}-1.91 \cdot Q+4.57 .
$$

The obtained dependence of the total required cargo capacity $\left(Q_{s}\right)$ of tank vehicles on their contents $(Q)$ is described by the linear equation:

$$
Q_{s}=4.15 \cdot Q+8.41 \text {. }
$$

The resulting dependence of the demand $(N)$ on tank trucks on their payload $(Q)$ is described by the polynomial of the fourth degree:

$$
N=2.2 \cdot 10^{-3} \cdot Q^{4}-8.23 \cdot 10^{-2} \cdot Q^{3}+1.11 \cdot Q^{2}-6.48 \cdot Q+18.72 .
$$

The received volume of investments $(V)$ in the fleet of tank-vehicles from their carrying capacity $(Q)$ is described by a polynomial of the second degree:

$$
V=0.28 \cdot Q^{2}+4.32 \cdot Q+56.055
$$

In the obtained dependencies (Fig. 2-5) the correlation ratio is 0.99 , which indicates a strong connection between the functional and cost indicators of the tank vehicle use and their capacity. These dependencies indicate that the type of tank-vehicles for the transport of milk and their parameters affect the functional parameters and the volume of investments in the tank vehicle park.

With regard to the total cargo car fleet of tank vehicles (Fig. 3), it increases in proportion to the selected capacity of tank vehicles, which is described by the linear equation. The analysis of the graph shown in Fig. 4 shows that with the increase in the load of tank vehicles in the structure of the park of the processing enterprise, their number decreases by the polynomial of the fourth degree.

Based on the obtained dependencies (Fig. 2-4), it can be affirmed that the limitation of the duration of individual routes ( $\left[t_{\text {lim }}\right]=3$ hours) leads to the fact that tank trucks with a capacity of more than 5.2 tons have approximately the same daily distance traveled (Fig. 2) and the need for them does not depend on the load $N=5$ units (Fig. 4).

This is due to the fact that the formation of separate routes using heavy-duty tankers is limited by the length of these routes. This causes the tankers to be under-load and consequently reduces the 
utilization rate of their tanks. At the same time, the content and number of routes remain almost unchanged.

Analysis of the milk truck functioning indicators (Fig. 2-5) convinces that with the increase in the load capacity of tank vehicles in the fleet structure, current and capital costs have opposite trends in change. They are the basis for finding optimal parameters of the milk trucks at the milk processing enterprise.

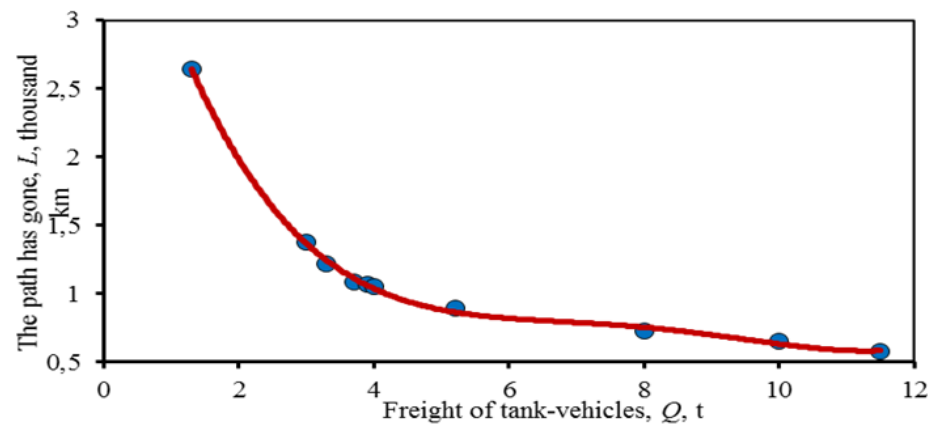

Fig. 2. Dependence of the total daily traveled way of tank vehicles on their cargo capacity

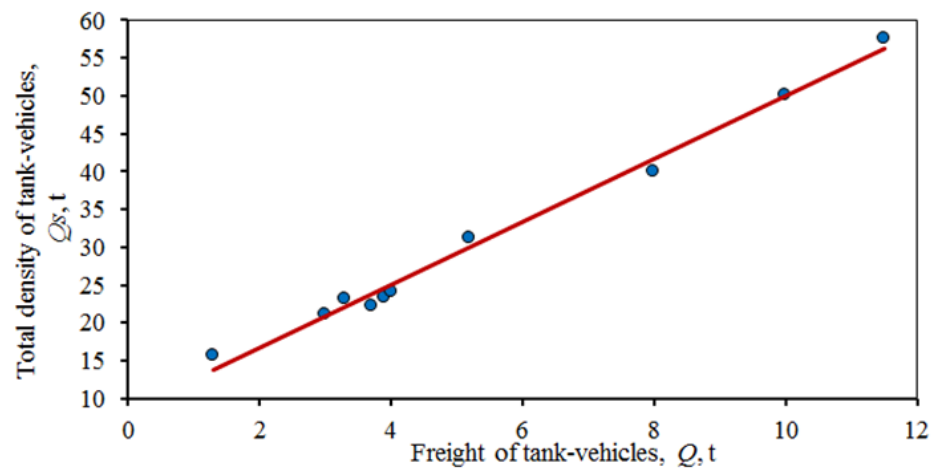

Fig 3. Dependence of the total required load of tankers on their capacity

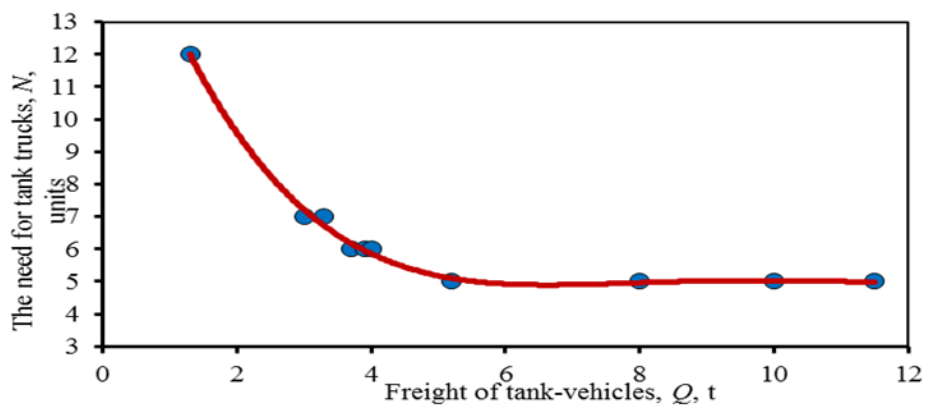

Fig 4. Dependence of demand on tank trucks on their payload

The increase in the tanker truck capacity of more than 5.2 tons leads to a decrease in the loading factor, a significant increase in the total required cargo capacity (Fig. 3) and the volume of investments in the tanker truck (Fig. 5). This indicates that it is inappropriate for the given production conditions (PJSC "Brody factory of skimmed milk powder" in Brody, Lviv region) to use tank trucks with a capacity of more than 5.2 tons.

The results of the conducted research indicate (Fig. 5) that the total consolidated expenses of funds for the export of the annual volume of harvested milk, subject to the attraction of tankers of the same load capacity, vary within the limits of 64.12-142.37 thousand USD. Minimal specific aggregate expenditures of funds fall into the variant involving the tank-vehicles GAZ-3309 + Г6-OTA-3.7 with the carrying capacity of 3.7 tons, which should be at the enterprise 6 units. For peak periods of milk harvest, in the structure of the fleet of tankers, there should be specialized trailers for the transport of milk with a cargo of 0.9 tons. 


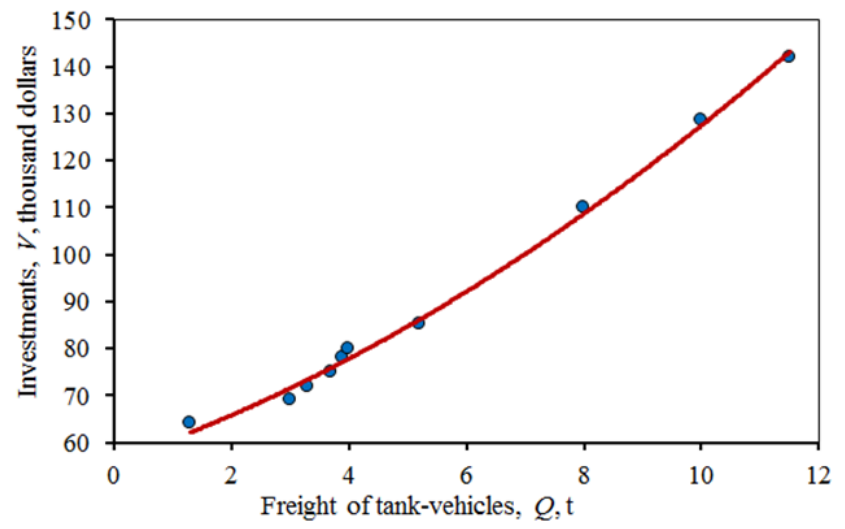

Fig 5. Dependence of the volume of investments in the fleet of tank vehicles on their freight capacity

\section{Results and conclusions}

The developed method of synthesis for four groups of factors of milk truck efficiency at the dairy processing enterprise is based on purposeful machine experimentation with the simulation model and substantiation of rational routes for variable characteristics of tank vehicles. It takes into account the volatile time of milk transportation, as well as the duration of successive calendar periods, which makes it possible to determine by a numerical method the optimal number and structure of the tank fleet at the dairy processing enterprise.

Based on the proposed method, computer experiments and calculations were carried out, which made it possible to identify the causal relationships between the load of tank vehicles and their required quantity for the period of intensive milk flow, total cargo, current and capital expenditures for the export of annual milk volume, which have close correlation and underlie optimization calculations. The opposite nature of the trends in current and capital cost changes is the basis for the search for a cost criterion for the basic variant of the milk truck parameters, which is determined by the numerical method.

It was established that the minimum specific aggregate expenditures of funds belong to the variant with the involvement of GAZ-3309 + Г6-OTA-3.7 tank-vehicles with a carrying capacity of 3.7 tons, which need to have at the enterprise of 6 units. For peak periods of milk harvest, in the structure of the tanker fleet, there should be specialized trailers for the transport of milk with a cargo of 0.9 tons. The expected annual economic effect of the proposed milk trucks for Brody Plant of Skimmed Milk in Brody, Lviv Oblast is 16.753 USD.

The results of the study can be used for other enterprises in different sectors of the economy where road transport occurs.

\section{References}

[1] Aleksejevs R. Groupage Cargo Transportation Model [Text] / Ruslans Aleksejevs, Raufs Guseinovs, Alexander N. Medvedev // Transport and Telecommunication. - 2016. - Vol. 17, No. 1. - pp. 60-72.

[2] Liotta G., Stecca G., Kaihara T. Optimisation of freight flows and sourcing in sustainable production and transportation networks. International Journal of Production Economics, 2015, 164, pp. 351-365.

[3] Petraška A. Methodology of Selection of Heavy and Oversized Freight Transportation System [Text] / Artūras Petraška, Kristina Čižiūnienè, Olegas Prentkovskis and Aldona Jarašūnienė // Transport and Telecommunication. - 2018. - Vol. 19, No. 1. - pp. 45-58.

[4] Bazaras, D., Batarlienè, B., Palšaitis, R., Petraška, A. Optimal road route selection criteria system for oversize goods transportation. The Baltic Journal of Road and Bridge Engineering, 2013, 8(1), pp. 19-24.

[5] Bula G.A., Prodhon C., Gonzalez F.A., Afsar H.M., Velasco N. Variable neighborhood search to solve the vehicle routing problem for hazardous materials transportation. Journal of Hazardous Materials, 2017, 324(Part B), pp. 472-480. 
[6] Doumiati M., Erhart S., Martinez J., Sename O., Dugard L. Adaptive control scheme for road profile estimation: application to vehicle dynamics. IFAC Proceedings Volumes, 47(3), 2014, pp. 8445-8450.

[7] Gardziejczyk W., Zabicki P. Normalization and variant assessment methods in selection of road alignment variants - case study. Journal of Civil Engineering and Management, 2017, 23(4), pp. 510-523.

[8] Newnam S., Goode N., Salmon P., Stevenson M. Reforming the road freight transportation system using systems thinking: An investigation of Coronial inquests in Australia. Accident Analysis \& Prevention, 2017, 101, pp. 28-36.

[9] Park S.W. Modelling of deformational characteristics in unbound granular geomaterials. KSCE Journal of Civil Engineering, 2004, 8(3), pp. 281-285.

[10] Pauer G. Development potentials and strategic objectives of intelligent transport systems improving road. Transport and Telecommunication Journal, 2017, 18(1), pp. 15-24.

[11] Сидорчук О. В., Тригуба А. М., Панюра Я. Й., Шолудько П. В. Особливості ситуаційного управління змістом та часом виконання робіт у інтегрованих проектах аграрного виробництва (Features of situational content management and execution time in integrated agricultural production projects) Eastern-European Journal of Enterprise Technologies. - 2010. Vol 1, No 2 (43), pp. 46-48. ( In Ukrainian).

[12] Тригуба А. М. Системно-проектні основи управління розвитком. технологічних структур виробництва молочної продукції (System-design basis of development management. technological structures of dairy production) 2017. D.Sc. Thesis (D.Sc. in Industrial Engineering). Odessa (In Ukrainian).

[13] Tryhuba A., Pavlikha N., Rudynets M. etc. Research on the effect of manufacturing conditions on the content of the performance of works in logistics systems of milk packaging. Eastern-European Journal of Enterprise Technologies: Control processes, 2019, 3 (3 (99)), pp. 50-63.

[14] Tryhuba A., Zachko O., Grabovets V. ect. Examining the effect of production conditions at territorial logistic systems of milk harvesting on the parameters of a fleet of milk trucks// EasternEuropean Journal of Enterprise Technologies. - 2018. - Vol 4, No 12 (95), pp. 59-70.

[15] Тригуба А. М., Луб П. М., Шарибура А. О., Грабовець В. В. Вплив територіального розташування пунктів заготівлі сільськогосподарської продукції на ефективність функціонування транспортної системи Influence of territorial location of points of purveyance of agricultural produce is on efficiency of functioning of a transport system Intercollegiate collection "Scientific notes" in the direction "Engineering mechanics" Lutsk National Technical University / 2014, vol. 45, 564-567. (In Ukrainian).

[16] Воркут Т. А. Проектний аналіз (Project analysis). Kyiv: Ukrainian Center for Spiritual Culture, 440. (In Ukrainian).

[17]Цвігун А.Т. Виробництво молока на малій фермі: практичн. посібник (Milk production on a small farm: practical manual). Кам'янець-Подільський, 2008. 216 c. ( In Ukrainian).

[18]Закон України "Про молоко та молочні продукти" (Law of Ukraine "On milk and dairy products) [online] [20.01.2020]. Available at: https://zakon.rada.gov.ua/laws/show/1870-15

[19] ISO9000 System approach to management Information.

[20] Nazarova O., Osadchyy V. Shulzhenko S. (2019). Accuracy Improving of the Two-Speed Elevator Positioning by the Identification of Loading Degree. International Conference Modern Electrical and Energy Systems (MEES-19). Kremencuk Mykhailo Ostrogradskyi Universitu, Ukraine. 2019. pp. 50-53. DOI: 10.1109/MEES.2019.8896414. 